\title{
Assessment of Cocoon Production of Eudrilus eugeniae through Bioconversion of Distillery Solid Waste with Elephant Dung
}

\section{Moorthi $\mathbf{M}^{1 *}$, Senthilkumar $\mathrm{A}^{2}$ and Srimathi $\mathbf{R}^{1}$ \\ ${ }^{1}$ Department of Zoology and Wildlife Biology, A.V.C College, India \\ ${ }^{2}$ Department of Zoology, ChikkaiahNaicker College, India}

*Corresponding author: Moorthi Mahaly, PG \& Research Department of Zoology and Wildlife Biology, A.V.C College (Autonomous), Mannampandal, Mayiladuthurai609 305, Tamilnadu, India, Tel: +91 7708857543; Email: moovim24@gmail.com

\section{Research Article \\ Volume 2 Issue 6}

Received Date: November 26, 2019

Published Date: December 17, 2019

DOI: $10.23880 /$ izab-16000192

\section{Abstract}

The dumping of organic wastes from the distillery industries leads serious threats to environment. The organic wastes disposal cause unpleasant odour, soil pollution, and distribution of vector borne diseases in human beings and highly infectious viral diseases which affects different animals. Bioconversion of distillery solid waste with elephant dung has been renowned and efficient technology used for reducing pollutants, making noble fertilizer and maintaining pollution free environment. The present study aimed at the bioconversion of distillery sludge combined with elephant dung using earthworm Eudrilus eugeniae Lin. and assessment the cocoon production. The three treatment combinations (T1-SD, T2ED and T3-SED) were selected and introduced the earthworm E. eugeniae for bioconversion. The physico-chemical characteristics were subjected for the initial day and final day (60 days).The results showed that the values of $\mathrm{pH}$, electrical conductivity, total nitrogen, total phosphorus, total potassium, total calcium and total magnesium were increased with a declining trend of total organic carbon and $\mathrm{C} / \mathrm{N}$ ratio from its initial value. From the results it was inferred that the organic wastes were effectively converted into a nutrient loaded vermicompost. The cocoon production of E. eugeniae was observed in all the treatments at different time intervals (0,15, 30, 45 and 60 days) were the higher level of cocoon production in SED combinations $114+38$ to $152 \pm 9.2$.Vermi- bioconversion is a appropriate method of using worms to transform organic waste into a nutrient-rich fertilizer, a healthy and a soil remediation from the pollution.

Keywords: Distillery Sludge; Elephant Dung; Cocoon; Eudrilus eugeniae 


\section{International Journal of Zoology and Animal Biology}

\section{Introduction}

The human society is dependent upon the agriculture for the fundamental needs like food, clothing and shelter. Due to the intensive farming system, the depletion of soil nutrients occur to a greater degree which creates an imbalance in nutrient availabilities, loss of soil fertility and drastic reduction of crop production. Nowadays, organic waste management and recycling processes become more essential towards fulfilling partial requirement of plant nutrients and sustainable soil health through enhancing the physico-chemical properties and the microbial diversity. In addition, a steady rise in fertilizer prices and increase in farm energy costs make burden to the farmers and these have necessitated organic waste recycling through eco- friendly technologies for sustainable agriculture. Distillery industry is one which produces enormous quantity of liquid and solid wastes that can be a great source of energy for recycling through green technologies. This not only be proved to be manure but also to a certain extent a solution to the problem of pollution [1].

Disposal of organic waste can be done by many methods like land filling, incineration, pyrolysis, recycling, conversion to biogas and composting. In terms of both organic waste management and environmental protection, vermin-bioconversion can be the most suitable method. In general, composting is the most widely applicable process of handling biodegradable organic wastes, which provides a way not only of reducing the amount of waste that needs to be disposedoff, but also concretes way to convert it into a product that is useful for agriculture. As a natural process, composting has many advantages. It is an effective and environmentally acceptable method for organic waste disposal which helps to recycle valuable nutrients to soil and plants ecosystems. Appropriate techniques of composting organic wastes with suitable additives can greatly improve fertilizer value of manures and at the same time it accomplishes protection of the environment [2].

Vermicompost, a by-product of earthworm facilitated organic waste re-cycling, is rich in plant nutrients and growth promoting substances and considered as an inseparable component of sustainable farming. Several factors, such as soil, temperature, substrate moisture, waste substrate, besides stocking rate of earthworm density influence to the extent of success of vermicomposting processes [3].
Earthworms voraciously feed on organic wastes and while utilizing only a small portion for their body synthesis they excrete a large part of these consumed waste materials in a half digested form. Since the intestines of earthworms harbor wide ranges of microorganisms, enzymes, hormones, etc., these partially digested materials decompose rapidly and transformed into a form of vermicompost within a short time [4]. The present study focused on the assessment of the cocoon production of E. eugeniae through vermi-bioconversion of distillery solid waste with elephant dung.

\section{Materials and Methods}

The earthworm African night crawler (E. Eugeniae Lin.) was obtained from a vermicomposting unit of A.V.C. College (Autonomous), Mannampandal, Nagapattinam District, Tamil Nadu, India. The clay soil was collected from nearby the agricultural land. The elephant dung was obtained from at Mayuranathar temple for this study. Distillery sludge was collected from distillery unit, Erode District, Tamil Nadu, India. From the collected substances, the small portions were dried, powdered and subjected for physico-chemical characterization. The experimental setup adopted by pot culture methods and quantity of composts were used in $20 \mathrm{~kg}$.

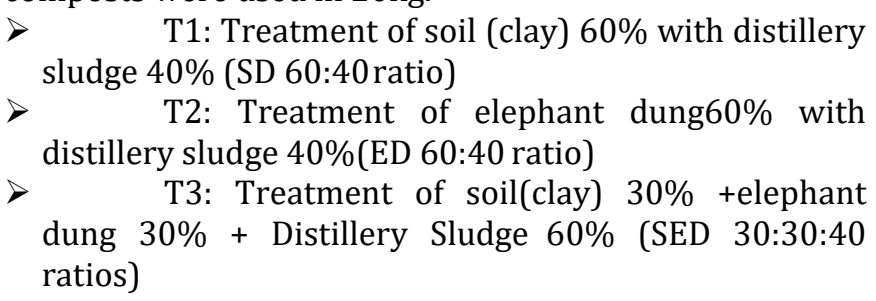

The earthworm was identified and further confirmed by the method suggested in manual of Julka, et al. [5]. The E. eugeniae being an epigeic form; it came up over the surface only for feeding and spent the remaining time under the soil. So that earthworm beds were designed to feel at home by placing small twigs at the bottom of the pot and small stone over it up to $10 \mathrm{~cm}$. Earthworm beds formed by concrete rings to be constructed to a height of $13 \mathrm{~cm}$ and a width of $25 \mathrm{~cm}$ and length $40 \mathrm{~cm}$ (round) to be fixed. The 25 young clitellated earthworms, weighing $250-300 \mathrm{mg}$ were introduced in the earthworm treatments beds (T1-SD, T2-ED and T3- SED).

\section{Analytical Methods}

The following standard analytical methods were adopted for initial and final analysis of clay soil and elephant dung by the following standard methods used. 
The $\mathrm{pH}$ was analyzed in sample-water suspension at 1:10 ratio by using $\mathrm{pH}$ meter [6]. Electrical conductivity (EC) was analyzed in sample-water suspension at 1:10 ratio by using Electrical conductivity meter [6]. Total organic carbon (TOC) was made by chromic acid wet digestion method [7]. Total nitrogen (TN) was analysed in compost and Vermicompost. For nitrogen analysis Macro-Kjeldahl method was made [8]. Total phosphorus (TP) was observed using colorimetric method with molybdenum in sulphuric acid by vanadomolybdate yellow color method and total potassium (TK) was analysed by flame photometric method [9]. Available nitrogen was analysed by alkaline permanganate method [10]. Available phosphorous was measured using colorimetric method $\left(0.5 \mathrm{M} \mathrm{NaHCO}{ }_{3}\right.$ extract) [11]. Available potassium was analysed using flame photometry (N-NH4OAc extract) [12]. Total calcium (TCa) and total magnesium (TMg) were analysed by triple acid digestion and extraction $\left(\mathrm{HNO}_{3}: \mathrm{H}_{2} \mathrm{SO}_{4}: \mathrm{HCIO}_{4}\right.$ at 9:2:1) - versenate method [13].

\section{Cocoon Production}

The cocoons were collected by mesh $(0 \times 5 \mathrm{~mm})$ sieve every day, using gentle washing, and their number was calculated per individual basis. The collected cocoons were separated in other soil medium.

\section{Statistical Analysis}

Two-way analysis of variance (ANOVA) was computed using SPSS (version 22) to test the level of significance of the difference between various treatments with respect to the physico-chemical parameters.

\section{Results and Discussion}

The $\mathrm{pH}$ in the SD combination was nearby neutral (7.1 \pm 0.5 to $7.1 \pm 0.5$ ), in ED combination, it was alkaline in nature $8.4 \pm 1.1$ to $7.8 \pm 1.2$ and in SED combination was nearby neutral $7.6 \pm 2.3$ to $7.2 \pm 2.5$. At end of the experiments, the $\mathrm{pH}$ in all the treatments was nearby neutral range was recorded (Figure 1 \& Table 1). The $\mathrm{pH}$ of all the vermicomposts was almost neutral and stabilized at matured stage ( 45 days) which may be due to the buffering nature of humic substances [14].

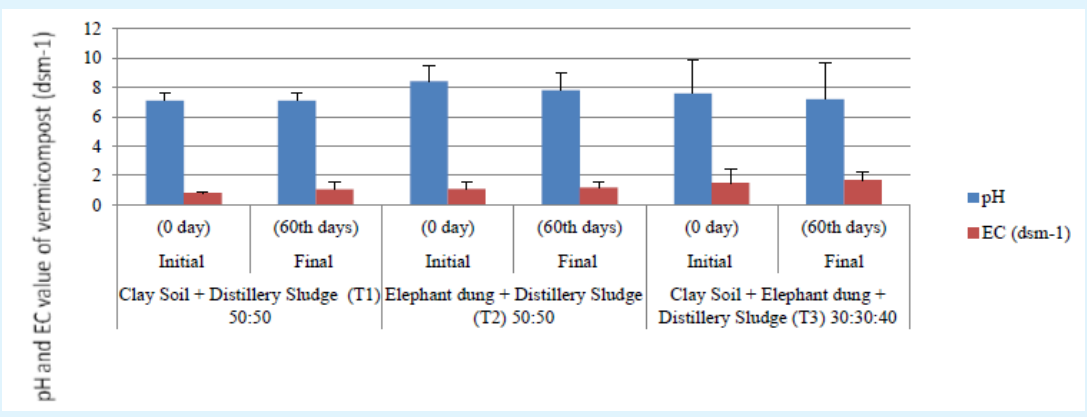

Figure 1: pH and EC (dsm-1) values in different combination of Vermicompost.

\begin{tabular}{|c|c|c|c|c|}
\hline S. No & Parameters & Clay Soil & Elephant dung & Distillery sludge \\
\hline 1 & $\mathrm{pH}$ & 7.2 & 8.2 & 4.6 \\
\hline 2 & $\mathrm{EC}(\mathrm{dsm}-1)$ & 0.5 & 0.8 & 28 \\
\hline 3 & C/N Ratio & 22 & 22 & 54 \\
\hline 4 & $\mathrm{TOC} \%$ & 41 & 42 & 0.4 \\
\hline 5 & $\mathrm{TN} \%$ & 0.5 & 0.5 & 0.3 \\
\hline 6 & $\mathrm{TP} \%$ & 0.4 & 0.5 & 0.6 \\
\hline 7 & $\mathrm{TK} \%$ & 0.6 & 0.6 & 0.3 \\
\hline 8 & $\mathrm{TCa} \%$ & 0.4 & 0.2 & 0.2 \\
\hline 9 & $\mathrm{TMg} \%$ & 0.2 & 0.3 & \\
\hline
\end{tabular}

Table 1: Physico chemical parameters of clay soil, elephant dung and Distillery sludge. 
The EC $\left(\mathrm{dsm}^{-1}\right)$ was gradually increasing in all the treatments from the initial stage to the final stage $(0.8 \pm 0.1$ to $1.05 \pm 0.5$ in SD combination; $1.08 \pm 0.5$ to $1.2 \pm 0.4$ in ED combination and $1.5 \pm 0.9$ to $1.7 \pm 0.5$ in SED Combination
(Figure $2 \&$ Table 2). This was due to the absorption of soluble salts by earthworms and enhanced microbial activities of the substances [15].

Figure 2: $\mathrm{C} / \mathrm{N}$ ratio and TOC\% values in different combinations of Vermicompost.

\begin{tabular}{|c|c|c|c|c|c|c|c|}
\hline \multirow{4}{*}{ S. No } & \multirow{4}{*}{ Parameters } & \multirow{2}{*}{\multicolumn{2}{|c|}{$\begin{array}{c}\text { Clay Soil + Distillery } \\
\text { Sludge (T1) }\end{array}$}} & \multirow{2}{*}{\multicolumn{2}{|c|}{$\begin{array}{c}\text { Elephant dung + Distillery } \\
\text { Sludge (T2) }\end{array}$}} & \multirow{2}{*}{\multicolumn{2}{|c|}{$\begin{array}{c}\text { Clay Soil + Elephant dung + Distillery } \\
\text { Sludge (T3) }\end{array}$}} \\
\hline & & & & & & & \\
\hline & & Initial & Final & Initial & Final & Initial & Final \\
\hline & & (0 day) & (60 $0^{\text {th }}$ days) & (0 day) & (60 ${ }^{\text {th }}$ days) & (0 day) & (60 $0^{\text {th }}$ days) \\
\hline 1 & $\mathrm{pH}$ & $7.1 \pm 0.5$ & $7.1 \pm 0.5$ & $8.4 \pm 1.1$ & $7.8 \pm 1.2$ & $7.6 \pm 2.3$ & $7.2 \pm 2.5$ \\
\hline 2 & $\mathrm{EC}(\mathrm{dsm}-1)$ & $0.8 \pm 0.1$ & $1.05 \pm 0.5$ & $1.08 \pm 0.5$ & $1.2 \pm 0.4$ & $1.5 \pm 0.9$ & $1.7 \pm 0.5$ \\
\hline 3 & C/N Ratio & $21.5 \pm 5.2$ & $15.2 \pm 3.2$ & $22 \pm 5.6$ & $18 \pm 1.5$ & $23 \pm 5.1$ & $14 \pm 3.1$ \\
\hline 4 & TOC\% & $43 \pm 5.9$ & $34 \pm 5.2$ & $44 \pm 7.2$ & $38 \pm 5.3$ & $46 \pm 5.7$ & $28 \pm 3.5$ \\
\hline 5 & TN\% & $0.6 \pm 0.01$ & $1.7 \pm 0.5$ & $0.5 \pm 0.1$ & $0.9 \pm 0.2$ & $1.8 \pm 0.3$ & $2.9 \pm 0.5$ \\
\hline 6 & TP\% & $0.5 \pm 0.01$ & $1.5 \pm 0.5$ & $0.8 \pm 0.1$ & $1.1 \pm 0.3$ & $1.1 \pm 0.5$ & $2.5 \pm 0.5$ \\
\hline 7 & TK\% & $0.8 \pm 0.02$ & $1.9 \pm 0.5$ & $0.7 \pm 0.1$ & $0.9 \pm 0.2$ & $1.4 \pm 0.5$ & $2.6 \pm 0.5$ \\
\hline 8 & TCa\% $\%$ & $0.5 \pm 0.01$ & $1.6 \pm 0.5$ & $0.5 \pm 0.1$ & $0.6 \pm 0.1$ & $1.2 \pm 0.5$ & $1.9 \pm 0.5$ \\
\hline \multirow[t]{3}{*}{9} & $\mathrm{TMg} \%$ & $0.2 \pm 0.1$ & $1.1 \pm 0.3$ & $0.3 \pm 0.1$ & $0.5 \pm 0.1$ & $0.7 \pm 0.5$ & $1.2 \pm 0.5$ \\
\hline & P Value & $0.002^{*}$ & & $0.001^{*}$ & & $0.001^{*}$ & \\
\hline & & \multicolumn{2}{|c|}{ Significant $* \mathrm{P}<0.05$} & \multicolumn{3}{|c|}{ Non-significant ${ }^{* *} \mathrm{P}>0.05$} & \\
\hline
\end{tabular}

Table 2: Physico chemical parameters in different combination of Vermicompost.

The $\mathrm{C} / \mathrm{N}$ ratio is one of the most widely used indicators of Vermicompost maturation and generally the ranges from 14 to 22 [16]. Figure 2 \& Table 2 showed decreased sharply during vermicomposting. The present results it was within this range except in SED combination. This may be due to the high amount of carbon present in the distillery sludge. According to Senesi, et al. [17] declined C/N ratio (less than 20) is the indications of the advanced degree of organic matter stabilization and reflects a satisfactory degree of organic wastes.

The total organic carbon ranges were slowly reduced from its initial stage (Figure $2 \&$ Table 2). Significantly lower TOC $\%$ of all the treatments suggested enhanced oxidation of organic carbon, as the results of the increased microbial activity. The loss of TOC may be due to the conversion of $\mathrm{CO}_{2}$ through microbial respiration and mineralization of organic matter causing an increase in total nitrogen and also microorganisms use the carbon as a source of energy decomposing the organic matter [18]. Total NPK were significantly increased in $60^{\text {th }}$ day of vermicomposting (Figure $3 \&$ Table 2). The high levels of NPK\% in SED were observed $(1.8 \pm 0.3$ to $2.9 \pm 0.5$ in TN $1.1 \pm 0.5$ to $2.5 \pm 0.5$ in TP\% and $1.4 \pm 0.5$ to $2.6 \pm 0.5$ in $\mathrm{TK}$ ) followed by other treatments. Significantly higher TN\% content suggested the superior composting ability of $E$. eugeniae. According to Padmavathiamma, et al. [19] the vermicompost contains a comparatively high level of nitrogen compared to other bulky organic manures. 
Generally, TN content in the vermicomposting range from 1.8 to $2.9 \%$. The increasing trend of TN may be due to the mineralization of the organic present. Similar results were also shown by Carbera, et al. [20]. The other nutrients $\mathrm{TP} \%$ and $\mathrm{TK} \%$ levels in treatments indicate that a higher mineralization rate occurs during the process of vermicomposting. Earthworms turn the insoluble and particulate organic matter into soluble forms with the help of solubilizing microorganisms present in the gut making it more available for the future plantations [1].

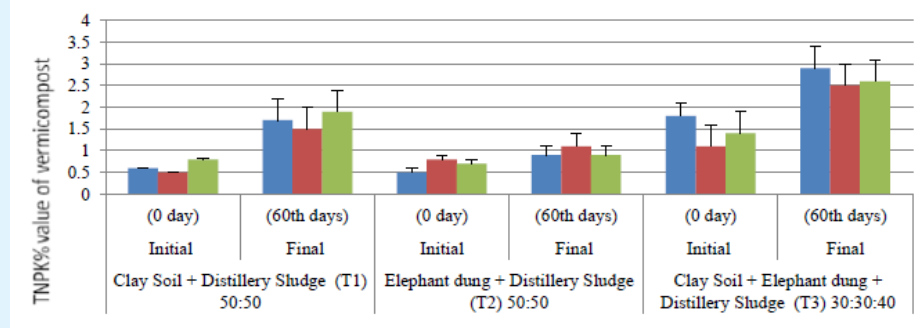

$=\mathrm{TN} \%$

$=\mathrm{TP} \%$

$=\mathrm{TK} \%$

Figure 3: TNPK\% values in different combinations of Vermicompost.

TCa and TMg were significantly increased from the initial day to $60^{\text {th }}$ day in all treatments (Figure 4 \& Table 2). Moorthi, et al. [18] reported when the micronutrients level was monitored, the higher $\mathrm{TCa} \%$ and $\mathrm{TMg} \%$ content were recorded in the matured vermicomposts produced by Eisenia fetida. Thus the solid wastes, SED combination was recycled into a nutrient-rich vermicompost successfully in this project with the help of the earthworm, E. eugeniae.

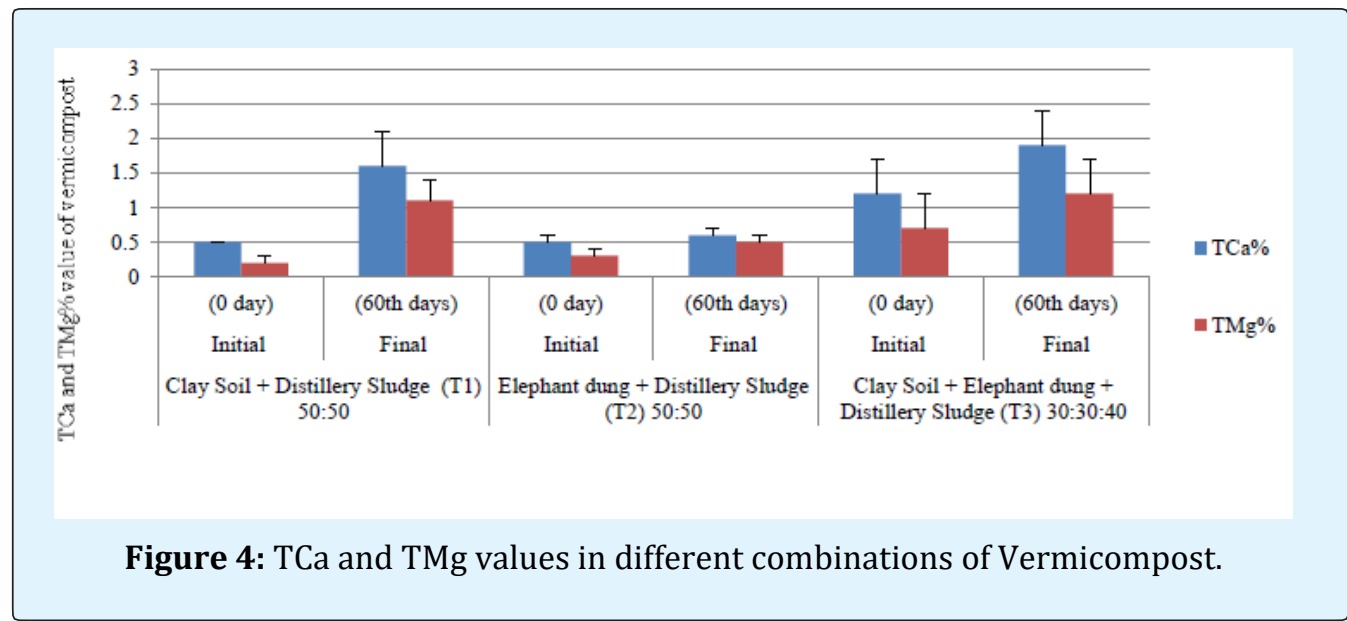

\section{Cocoon Production}

The cocoon productions of E. eugeniae were observed in all the treatments on $0,15,30,45$ and 60 days. The high level of cocoon productions was recorded in SED combination ( $36 \pm 8.8$ to $42 \pm 9.2)$ with when increased experimental days (Figure 5 \& Table 3). The similar results were observed in SD $(22+8.6$ to $33 \pm 7.8)$ and in ED $(28+6.6$ to $35 \pm 6.9)$ from initial to $60^{\text {th }}$ day. Viljoen, et al. [21] reported the fibrous tips at both ends of the cocoon in the African epigeic worm, E. eugeniae. While cocoons are produced by cross-fertilization between two adult worms in many species, in others there may be selffertilization or parthenogenesis. The shape, size, development time and hatching success of cocoons differ greatly among earthworm species. The highest and lowest size and weight of cocoons were found in the giant anecic worm Eutyphoeus gammiei and the smallest epigeic earthworm Dichogaster modiglianii respectively [22]. 


\section{International Journal of Zoology and Animal Biology}

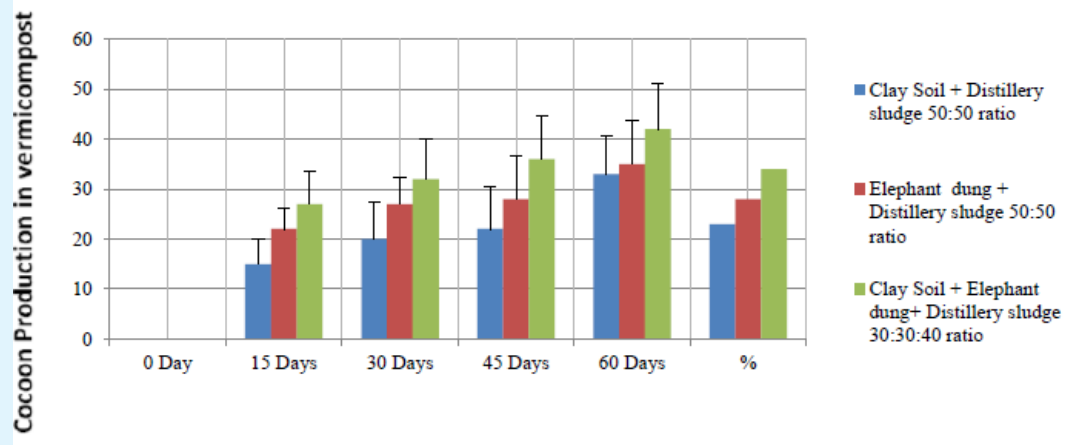

Figure 5: Earthworm Eudrilus eugeniae Lin. Cocoon production in different combination of Vermicompost.

\begin{tabular}{|c|c|c|c|c|c|c|c|c|}
\hline $\begin{array}{l}\text { S. } \\
\text { No }\end{array}$ & Treatments & $\begin{array}{c}0 \\
\text { Day }\end{array}$ & $\begin{array}{c}15 \\
\text { Days }\end{array}$ & \begin{tabular}{c|}
30 \\
Days
\end{tabular} & \begin{tabular}{|c|}
45 \\
Days
\end{tabular} & $\begin{array}{c}60 \\
\text { Days }\end{array}$ & $\begin{array}{l}\text { Percentage } \\
\text { (\%) }\end{array}$ & $\begin{array}{l}\mathrm{P}<\text { Value } \\
0.05\end{array}$ \\
\hline 1 & Cocoon production in Clay Soil + Distillery (T1) & 0 & $15 \pm 5.1$ & $20 \pm 7.3$ & $22 \pm 8.6$ & $33 \pm 7.8$ & $23 \%$ & $0.0001^{*}$ \\
\hline 2 & Cocoon production in Elephant dung + Distillery (T2) & 0 & $22 \pm 5.1$ & $27 \pm 5.3$ & $28 \pm 6.6$ & $35 \pm 6.9$ & $28 \%$ & $0.0001^{*}$ \\
\hline 3 & $\begin{array}{c}\text { Cocoon production in Clay Soil + Elephant dung+ } \\
\text { Distillery (T3) }\end{array}$ & 0 & $27 \pm 6.7$ & $32 \pm 7.9$ & $36 \pm 8.8$ & $42 \pm 9.2$ & $34 \%$ & $0.0001^{*}$ \\
\hline & Significant* $\mathrm{P}<0.05 \mathrm{No}$ & ia & ficant* & $P>0$ & & & & \\
\hline
\end{tabular}

Table 3: Cocoon production in different combination of Vermicompost.

\section{Conclusion}

In short, the bioconversion of distillery sludge as vermicomposts provides a sound solution for their disposal as well as the problem of pollution. The physicochemical properties observed that the values of $\mathrm{pH}$, electrical conductivity, total nitrogen, total phosphorus and total potassium, total calcium and total magnesium were increased with a declining trend in total organic carbon and $\mathrm{C} / \mathrm{N}$ ratio from its initial value. Finally, the organic wastes were effectively changed into a nutrient loaded Vermicompost, the higher level of cocoon productions in SED combination. The disposal of solid wastes as manures help in meeting the nutrient requirement of crops as well as sustaining soil health by maintaining soil organic matter status. Thus it proves that the bioconversion techniques are economically viable, socially acceptable and environmentally sensible one to the industrialists and for the farmers.

\section{References}

1. Moorthi M, Nagarajan K (2011) Biomanagement of distillery solid waste using earthworm Eudrilu seugeniae, J of Industrial Pollution Control 27 (2): 169-172.
2. Choudhari PS, Pal TK, Bhattacharjee G, Dey SK (2001) Nutrient changes during vermicomposting by Perionyx excavates on the specific used, Trapa bispinosa. Philipp J Scie 130: 127-133.

3. Moorthi M, Abbiramy KS, Senthilkumar A, Nagarajan K (2017) Vermitechnology An Eco Biological Tool for Sustainable Environment. Biotech Sustainability pp: 41-50.

4. Moorthi M, Nagarajan K, Senthilkumar A (2016) Vermi-technology of organic solid waste with using earthworm Eudrilus eugeniae . J zoo studies 3(4): 4851.

5. Julka JM (1988) The fauna of India and the Adjacent Countries, Megadrile: Oligochaeta. pp: 1-415.

6. Falcon MA, Corominas E, Perez ML, Perestelo F (1987) Aerobic bacterial populations and environmental factors involved in the composting of agricultural and forest wastes of the Coronary islands. Biol Wastes 20: 89-99.

7. Walkley A, Black CA (1934) An estimation of different methods for determining soil organic matter and a proposed modification of the chromic acid titration method. Soil Sci 37: 29-38. 
8. Humphries EC (1956) Mineral components and ash analysis. In: Modern method of plant analysis. Springer Verlar, Berlin 1: 468-502.

9. Jackson ML (1973) Soil Chemical Analysis. Prentice Hall of India Pvt. Ltd., New Delhi, India pp: 498.

10. Subbaiah BV, Asija GL (1956) A rapid procedure for the estimation of the available nitrogen in soils. Curr Sci 25: 259-260.

11. Olsen SR, Cole CV, Wantanabe FS, Denn AL (1954) Estimation of available phosphorous in soils by extraction with sodium bicarbonate.

12. Stanford G, English L (1949) Use of flame photometer in rapid soil tests for $\mathrm{K}$ and Ca. Agron J 41: 446-453.

13. Piper CS (1966) Soil and Plant Analysis. Hans Publication, Bombay, India pp: 236.

14. Allison FE (1973) Soil organic matter and its role in crop production. $1^{\text {st }}$ (Edn.), Elsevier Publishers, New York 3: 634.

15. Kumar V, Singh KP (2016) Enriching vermicompost by nitrogen fixing and phosphate waste with using earthworm Eudrilus eugeniae. The Journal of Zoology Studies 3(4): 48-51.

16. Christopher MSM (1996) Recycling of plantation agro-wastes. Planters chronicle 91(2): 53-61.

17. Senesi N (1989) Composted Materials as Organic Fertilizers. The Sci Total Environ 81-82: 521-524.

18. Moorthi M, Abbiramy KS, Senthilkumar A, Chitrapriya K, Nagarajan K (2018) Vermicomposting of distillery sludge waste with tea leaf residues. Sustainable Environment Research 28(5): 223-227.

19. Padmavathiamma PK, Li IY, Kumari UR (2008) An experimental study of vermi-biowaste composting for agricultural soil improvement. Biores. Technol 99(6): 1672-1681.

20. Carbera ML, Kissel DE, Vigil MF (2005) Nitrogen mineralization from organic residues. Res Oppur J Enviro Qual 34: 75-79.

21. Viljoen SA, Reinecke AJ (1989) The life cycle of the African night crawler, Eudrilu seugeniae (Oligochaeta). S Afr J Zool 24(1): 27-32.

22. Lavelle $P$ (1981) Reproductive strategies in earthworms. Acta Oecol 21: 17-133. 